JRPB, Vol. 6, No. 2, September 2018, Hal. 188-196

DOI: https://doi.org/10.29303/jrpb.v6i2.81

ISSN 2301-8119, e-ISSN 2443-1354

Tersedia online di http://jrpb.unram.ac.id/

\title{
ALGORITME IMAGE PROCESSING PENDUGAAN LUASAN SERANGAN PENYAKIT TUNGRO PADA PADI MELALUI PENDEKATAN FOTO UDARA
}

\author{
Image Processing Algorithm for Estimate the Area of Tungro Disease Attacks on Rice \\ Through Aerial Photography Approach
}

\author{
I Gede Arya Megantara ${ }^{1, *)}$, I Made Anom S. Wijaya ${ }^{1}$, I Putu Gede Budisanjaya ${ }^{1}$ \\ ${ }^{1}$ Program Studi Teknik Pertanian, Fakultas Teknologi Pertanian, Unud \\ Email $^{*}$ : mega.arya18@gmail.com
}

Diterima: Juli 2018

Disetujui: September 2018

\begin{abstract}
Tungro is one cause of crop failure. The calculation of the extent of the attack is very important to determine dimension of the attack on a land. Aerial photograph is one of the technologies that can be used to predict the extent of tungro disease. The development of image processing algorithms should be developed to predict the extent of attacks with aerial photographs. The purpose of this research was to develop an application that can be used to predict the extent of tungro disease on rice field. Adobe Photoshop CS 6 and Matlab R2013a were used to develop the program to estimate the attacked area. This research consists of several steps, i.e image acquisition, preprocessing, thresholding, image morphology operation, pixel calculation, calculation of the area of attack. The algorithm of this study were: image acquisition, color normalization, mosaicking, resize, scale calculation, land pixel calculation, pixel attack calculation, calculation of attack area, and percentage of attack. T test is performed on data of percentage estimation of attack result from the aerial photograph algorithms and manual calculation using planimeter. From the $T$ test results obtained that both data were relatively similar, respectively $19,605 \%$ and $19,180 \%$.
\end{abstract}

Keywords: Image Processing analysis, aerial photography, attacked area, tungro

\begin{abstract}
ABSTRAK
Tungro merupakan salah satu penyebab kegagalan panen. Pendugaan luasan serangan sangat penting dilakukan untuk mengetahui besarnya serangan yang terjadi dan pendugaan hasil yang akan didapat. Foto udara merupakan salah satu teknologi yang dapat dikembangkan untuk menduga luasan serangan penyakit tungro. Tujuan dari penelitian ini adalah mengembangkan algoritme pendugaan luasan serangan penyakit tungro pada padi melalui pendekatan foto udara. Pengembangan algoritme pendugaan luas serangan menggunakan bantuan software Adobe Photoshop CS 6 dan Matlab R2013a. Penelitian ini terdiri dari beberapa tahapan, yaitu akuisisi citra, preprocessing, thresholding, operasi morfologi citra, perhitungan pixel, perhitungan luas serangan.
\end{abstract}


Algoritme pendugaan luas serangan adalah akuisisi citra, normalisasi warna, mosaicking, resize, perhitungan skala, perhitungan pixel lahan, perhitungan pixel serangan dan perhitungan persentase serangan. Perhitungan pixel lahan menggunakan proses thresholding dan penjumlahan pixel. Perhitungan pixel serangan menggunakan thresholding otsu, operasi morfologi citra dan penjumlahan pixel. Perhitungan persentase serangan menggunakan perbandingan pixel serangan dengan pixel lahan. Uji T dilakukan terhadap data pendugaan persentase serangan tungro hasil algoritme foto udara dan perhitungan manual dengan menggunakan bantuan planimeter. Dari uji T didapatkan hasil bahwa kedua data relatif sama, yaitu berturut-turut sebesar 19,605\% dan 19,180\%.

Kata kunci: analisis Image Processing, foto udara, luasan serangan, tungro

\section{PENDAHULUAN}

\section{Latar Belakang}

Tungro merupakan salah satu penyakit yang menyerang tanaman padi. Penyebab terjadinya tungro adalah virus bentuk batang Rice Tungro Bacilliform Virus (RTBV) dan virus bentuk bulat Rice Tungro Spherical Virus (RTSV) (Hibino, H., dkk., 1978; Omura, T, dkk., 1983). Penyakit tungro memerlukan vektor untuk menyebarkannya, wereng hijau terutama wereng hijau spesies Nephotettix Virescens adalah vektor yang paling berperan aktif (Sogawa, K.,1976; Siwi dan Suzuki, 1991). Serangan tungro pada tanaman padi akan menyebabkan pertumbuhan dan perkembangan menjadi terganggu, dimana tanaman akan menjadi kerdil, jumlah anakan sedikit dan kehampaan malai tinggi (Suzuki, Y., dkk., 1992). Pada serangan yang parah, tungro akan menyebabkan kerusakan panen atau kehilangan hasil sampai 100 persen.

Untuk menjamin kesejahteraan petani saat kegagalan panen yang terjadi, maka pemerintah mengeluarkan UndangUndang Nomor 19 Tahun 2013 tentang Perlindungan dan Pemberdayaan Petani, yang telah ditindaklanjuti dengan penerbitan Peraturan Menteri Pertanian No. 40 Tahun 2015 tentang Fasilitasi Asuransi Pertanian. Salah satu risiko yang ditanggung oleh asuransi adalah risiko akibat penyakit tungro. Klaim oleh petani hanya bisa dilakukan jika intensitas kerusakan dan atau luas kerusakan penyakit pada padi sudah mencapai $75 \%$ (Anonim, 2016).

Perhitungan serangan tungro di lapangan sejauh ini hanya menggunakan intensitas serangan. Perhitungan intensitas serangan yang ada di lapangan dilakukan secara visual berdasarkan gejala serangan (Manopo, R., dkk., 2013). Padahal luas serangan penyakit tungro terlihat cukup jelas. Perhitungan intensitas serangan memiliki kekurangan yaitu tenaga yang dihabiskan banyak dan waktu yang diperlukan sangat lama.

Ada beberapa teknologi yang bisa digunakan dalam membantu mengatasi kekurangan dari metode yang diterapkan seperti menggunakan satelit dan foto udara. Penggunaan satelit saat ini sudah mulai dilirik karena memiliki beberapa keuntungan seperti cakupan wilayah yang luas dan tenaga yang diperlukan sedikit. Akan tetapi penggunaan satelit memiliki beberapa kekurangan seperti detail foto hasil akusisi kurang jelas dan penggunaannya sangat tergantung cuaca, seperti hujan, awan, dan kabut karena pengoperasian dari luar angkasa, pemotretan masih belum bisa menembus awan (Wastono, M., 2013).

Selain metode satelit, salah satu metode yang dapat dikembangkan adalah metode foto udara. Keuntungan menggunakan metode ini adalah biaya operasional yang lebih terjangkau, detail gambar lebih bagus dari citra satelit dan tidak terkendala awan (Wastono, M., 2013). 


\section{Tujuan}

Tujuan dari pelaksanaan penelitian ini adalah melakukan pendugaan luasan serangan penyakit tungro pada padi menggunakan pendekatan foto udara.

\section{METODE PENELITIAN}

\section{Alat dan Bahan}

Alat - alat yang digunakan dalam penelitian ini meliputi alat akuisisi citra, alat pengolahan citra dan alat ukur. Alat pengolahan citra yang digunakan berupa Laptop Toshiba L645 dengan spesifikasi sebagai berikut: Intel core i3 processor, RAM 2 GB, Hard Disc 1TB yang dilengkapi dengan Sistem Operasi Windows 7, Software Matlab R2013a dan Software Adobe Photoshop CS 6. Alat ukur yang digunakan yaitu lightmeter, stopwatch dan planimeter. Alat akuisisi citra yang digunakan adalah papan skala, papan nomor dan Dji Phantom 4 dengan spesifikasi kamera seperti yang tertera pada Tabel 1 .

Tabel 1. Spesifikasi Kamera Dji Phantom 4

\begin{tabular}{ll}
\hline Sensor & 1/2.3"CMOS \\
& Effective pixels: $12.4 \mathrm{M}$ \\
Lens & FOV $94^{\circ} 20 \mathrm{~mm}(35 \mathrm{~mm}$ \\
& $\begin{array}{l}\text { format equivalent) } \mathrm{f} / 2.8 \\
\text { focus } \text { at } \infty\end{array}$ \\
ISO Range & $100-1600$ (photo) \\
Electronic & $8-1 / 8000 \mathrm{~s}$ \\
$\begin{array}{l}\text { Shutter Speed } \\
\text { Image Size }\end{array}$ & $4000 \times 3000$ \\
\hline
\end{tabular}

Sumber: https://www.dji.com/phantom-4/info

Bahan dalam penelitian ini adalah foto udara padi varietas towuti yang terserang penyakit tungro pada saat memasuki tahap pematangan gabah (umur 100-110 hari setelah tanam).

\section{Metode}

Penelitian ini dilaksanakan dengan beberapa tahapan, yaitu akuisisi citra, preprocessing, thresholding, operasi morfologi citra, perhitungan pixel, perhitungan luas serangan.

\section{Akuisisi Citra}

Akuisisi citra dilakukan pada jam 07.30 - 10.30 dan jam $15.00-17.00$ dengan intensitas cahaya berkisar antara $20.000-60.000$. Pada tahap ini juga juga dilakukan trial and error mengenai pengaturan drone agar memperoleh gambar detail serangan paling jelas.

Akuisisi foto udara dilakukan dengan mempertimbangkan kondisi lingkungan pada objek penelitian seperti cuaca, intensitas cahaya dan arah matahari. Akuisisi dilakukan pada cuaca cerah dengan intensitas cahaya pada kisaran 20.000 - 60.000 lux (Putra, S., dkk, 2016). Akuisisi foto udara dilakukan berlawanan dengan arah matahari, pada rentang jam 07.30-10.30 dan jam 15.0017.00. Range sutterspeed yang dilakukan adalah dari 200 dan 500, ISO yang digunakan adalah 100, dan focus yang digunakan adalah auto focus. Interval pengambilan adalah 3 detik dengan kecepatan $\pm 2,0 \mathrm{~m} / \mathrm{s}$.

\section{Preprocessing}

Preprocessing adalah tahapan yang dilakukan sebelum pengolahan dengan program. Tujuan dari tahapan ini adalah untuk memperoleh citra yang sesuai dengan program. Tahap preprocessing dilakukan dengan bantuan software Matlab R2013a. Pada tahap ini dilakukan trial and error pada citra hasil akusisi sehingga bisa didapatkan citra sesuai dengan kebutuhan program.

\section{Normalisasi Warna}

Selain itu dilakukan proses normalisasi warna citra menggunakan bantuan software Adobe Photoshop CS 6. Tahapan ini dilakukan dengan meningkatkan nilai kontras dan brightness. Besar nilai kontras yang ditambahkan adalah sebesar +60 . Range 
nilai brightness diatur mulai dari kisaran 20 sampai +60 .

\section{Mosaicking}

Mosaicking merupakan tahapan penggabungan beberapa foto udara. Mosaicking menggunakan bantuan software Adobe Photoshop CS 6. Proses mosaicking dilakukan dengan menumpuk setiap foto udara. Penumpukkannya dilakukan pada citra papan nomor untuk mengetahui titik perpotongan setiap gambar.

\section{Thresholding}

Threholding adalah tahapan mengubah citra hasil preprocessing menjadi citra Biner. Pada tahap ini dilakukan proses trial and error mengenai besarnya level thresholding dan jenis thresholding yang akan digunakan.

\section{Operasi Morfologi Citra}

Tujuan dari operasi morfologi citra adalah untuk menghilangkan noise yang terjadi saat proses thresholding. Pada tahap ini dilakukan trial and error pada jenis structuring elements (SE), besarnya SE dan tahapan operasi morfologi citra yang dilakukan. Resize citra adalah satu bentuk operasi morfologi yang dilakukan pada penelitian ini.

Resize atau perubahan citra dilakukan untuk memperkecil ukuran citra agar komputer mampu memproses citra dengan cepat dan tidak menghabiskan banyak memori penyimpanan di dalam Read Only Memory (RAM). Skala resize yang digunakan adalah $1 / 4$ kali.

\section{Perhitungan Pixel}

Setelah didapatkan citra biner yang lebih baik dari hasil operasi morfologi citra, selanjutnya dilakukan proses perhitungan pada pixel padi yang terserang penyakit tungro.

\section{Perhitungan Luas Serangan}

Luas serangan dihitung berdasarkan jumlah pixel serangan. Perhitungan luas serangan dapat dilakukan dengan mengetahui skala gambar dan ukuran aslinya. Tahapan perhitungan skala adalah cropping, papan skala, thresholding otsu, operasi morfologi citra dan perhitungan jumlah pixel papan skala.

Proses pertama yang dilakukan pada perhitungan skala adalah cropping. Tujuan dari proses ini adalah untuk hanya memilih citra papan skala yang selanjutnya akan diproses untuk bisa mendapatkan data jumlah pixel papa skala. Setelah proses cropping dilanjutkan dengan proses thresholding otsu. Proses thresholding dilakukan untuk memilih citra putih pada papan skala. Pemilihan citra putih karena hanya citra yang berwarna putih yang diketahui ukurannya untuk membuat skala.

Setelah itu, proses dilanjutkan dengan operasi morfologi citra. Operasi morfologi citra dilakukan untuk menghilangkan noise atau kesalahan yang ada pada pada saat proses thresholding. Hasil dari proses ini adalah citra berwarna putih yang menunjukkan citra papan skala berwarna putih. Setelah operasi morfologi citra, maka dilakukan perhitungan terhadap citra berwarna putih. Setelah mendapat jumlah pixel, dilakukan perhitungan untuk mendapatkan persamaan jumlah pixel dengan luasan serangan.

Persentase serangan adalah perbandingan antara luas serangan padi yang terkena penyakit tungro dengan luas lahan. Tahap pertama yang dilakukan adalah cropping, setelah itu baru dilakukan proses perhitungan pixel lahan dan pixel serangan. Tujuan dari proses cropping adalah untuk memotong citra selain petakan sawah yang akan dihitung luasan serangannya saja dan menghilangkan citra yang lain. Setelah itu dilanjutkan dengan perhitungan pixel lahan dan pixel serangan. 
Setelah luas serangan ditentukan selanjutnya dilakukan perbandingan perhitungan persentase serangan tungro untuk mengetahui seberapa akurat program yang digunakan untuk menduga persentase serangan penyakit tungro. Hingga saat ini tidak ada cara yang digunakan secara pasti di lapangan untuk melakukan perhitungan persentase serangan penyakit tungro, petugas hanya menggunakan perkiraan dalam melakukan perhitungan. Oleh karena itu, pada penelitian ini untuk dikembangkan cara untuk menghitung persentase secara manual menggunakan planimeter.

Data perhitungan persentase serangan penyakit tungro menggunakan program dan hitung manual dianalisis apakah hasilnya tidak sama atau berbeda, pengujiannya menggunakan uji $\mathrm{T}$.

\section{HASIL DAN PEMBAHASAN}

Analisis terhadap citra padi untuk menduga luasan serangan penyakit tungro dilakukan dengan menerapkan sejumlah algoritme pengolahan citra (Image Processing). Hasil normalisasi warna citra, mosaicking, resize citra, perhitungan skala dan perhitungan persentase serangan dijelaskan sebagai berikut.

\section{Normalisasi Warna Citra dan Mosaicking}

Hasil foto udara yang telah mengalami proses normalisasi warna dapat dilihat pada Gambar 1. Pada gambar tersebut terlihat bahwa foto udara setelah dinormalisasi memiliki tingkat kecerahan yang lebih tinggi, sehingga detail objek terlihat lebih jelas.

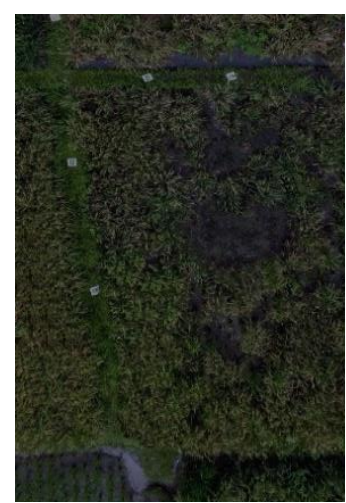

a

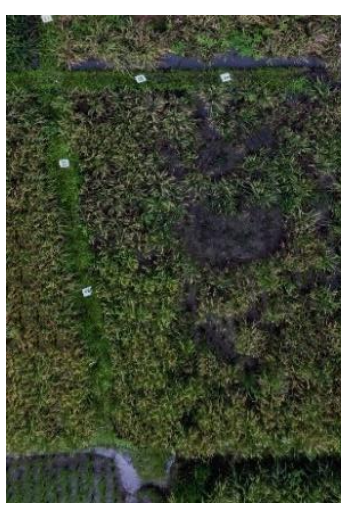

b
Gambar 1. Foto Normalisasi Warna, (a) Sebelum Proses Normalisasi Warna dan (b) Sesudah Normalisasi Warna

Hasil foto udara sebelum dan sesudah proses mosaicking dapat dilihat pada Gambar 2. Pada gambar tersebut terlihat bahwa setelah proses mosaicking dihasilkan gambar (c) yang lebih representatif dibandingkan sebelum diproses (Frame 1 (a), Frame 2 (b)).

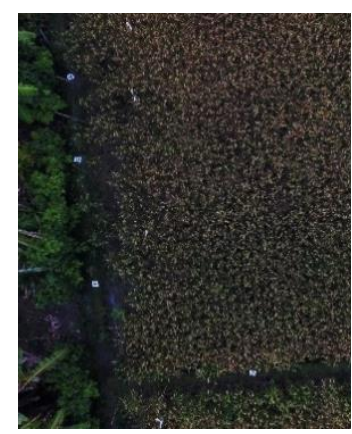

a

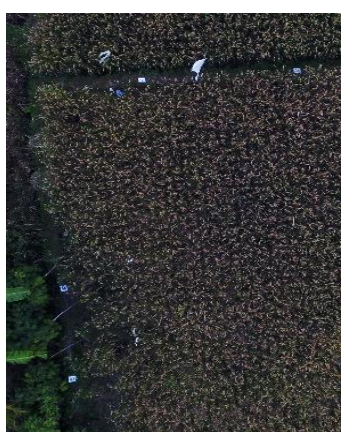

b

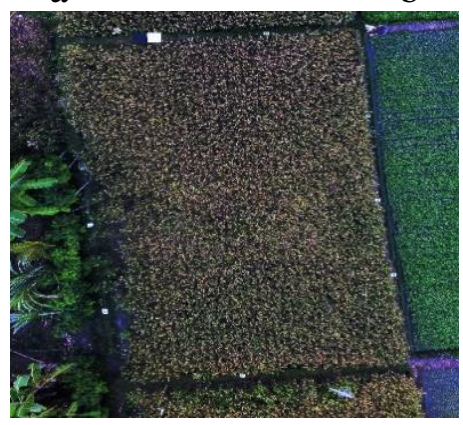

C

Gambar 2. Foto Udara Sebelum dan Sesudah Proses Mosaicking, (a) Sebelum Proses Mosaicking Frame 1, (b) Sebelum Proses Mosaicking Frame 2, (c) Setelah Proses Mosaicking 


\section{Resize Citra}

Hasil perbandingan citra sebelum dan sesudah proses resize dapat dilihat pada Gambar 3. Sebelum di-resize (a) hasil foto udara memperlihatkan detil yang kurang jelas. Setelah di-resize (b), detil pada hasil foto udara lebih jelas terlihat. Namun, setelah diperbesar $200 \%$, pada foto setelah resize, detil gambar menjadi sangat tidak jelas.

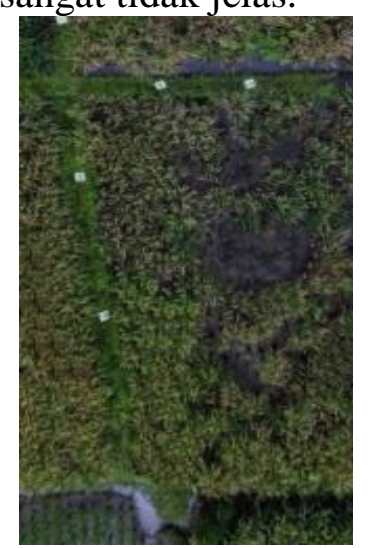

a

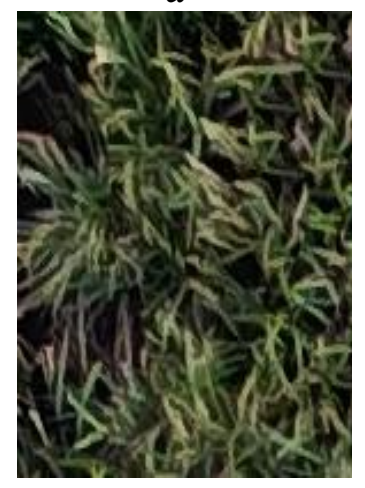

C

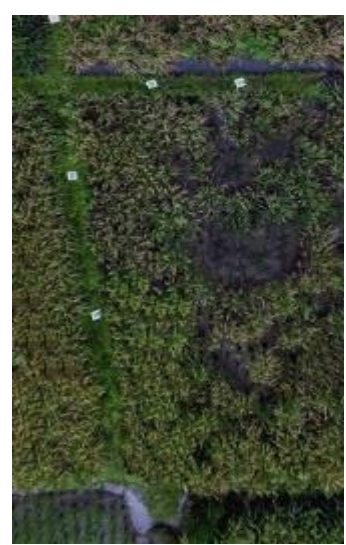

b

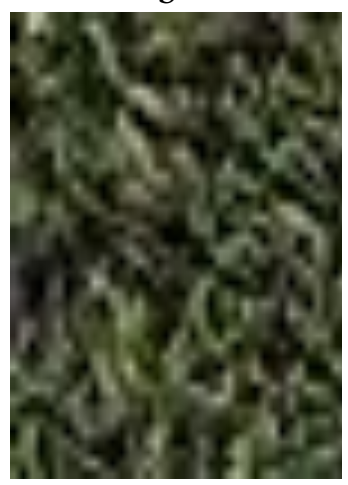

d
Gambar 3. Citra Sebelum dan Sesudah

Proses Resize, (a) Sebelum Proses Resize, (b)

Sesudah Proses Resize, (c) Citra Sebelum

Proses Resize dengan Pembesaran 200\%, (d)

Citra Sesudah Proses Resize dengan Pembesaran 200\%

\section{Perhitungan Skala}

Pada penelitian ini, koding perhitungan skala yang digunakan adalah sebagai berikut:

$\%$ croping papan skala

gb1 = handles.gambar;

axes(handles.layar1)

imshow(gb1)

papan_skala $=$ imcrop $(\mathrm{gb} 1,[])$;
$\%$ menampilkan gambar

axes(handles.layar3)

imshow(papan_skala);

$\%$ binerisasi papan skala

skala_abu = rgb2gray(papan_skala);

level = graythresh (skala_abu);

skala_bw =im2bw (papan_skala, level);

$\%$ morfologi citra

gb2 = bwareaopen(skala_bw,400);

$\%$ menghitung jumlah pixel

pixel_skala $=\operatorname{sum}(\mathrm{gb} 2(:))$;

set(handles.pixel_skala,'string',pixel_skala);

$\%$ membuat persamaan skala

skala_meter $=0.25 /$ pixel_skala;

handles.skala = skala_meter;

guidata(hObject, handles);

set(handles.tombol_crop,'Enable','on')

\section{Perhitungan Persentase Serangan}

Perhitungan Pixel Lahan

Setelah melalui proses cropping, citra selanjutnya dihitung luasan totalnya, nilai ini merepresentasikan luas lahan petani. Perhitungan luasan lahan sangat penting dilakukan karena perhitungan persentase serangan memerlukan data luasan serangan sebagai pembagi data luas serangan penyakit tungro.

Tahap pertama dalam perhitungan pixel lahan adalah proses thresholding. Tujuan dari proses thresholding ini adalah membuat citra petakan sawah petani menjadi berwarna putih dan yang lainnya berwarna hitam. Setelah didapatkan citra biner, dilanjutkan dengan proses perhitungan pixel. Luas lahan diperoleh dari perhitungan jumlah pixel satu lahan petani. Jumlah pixel luas lahan selanjutnya digunakan untuk perhitungan persentase serangan. Koding untuk perhitungan pixel lahan adalah sebagai berikut:

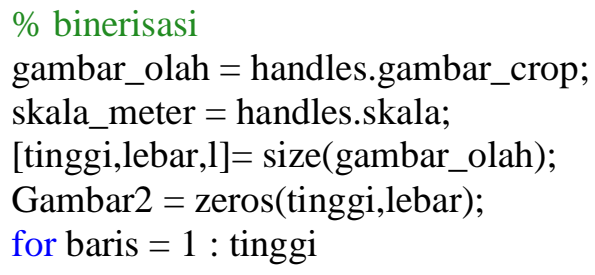


for kolom $=1$ : lebar

if gambar_olah(baris,kolom,1) $>0$ \& \&

gambar_olah(baris,kolom, 2$)>0 \& \&$

gambar_olah(baris,kolom,3)>0

Gambar2 (baris,kolom) $=1$;

end

end

end

$\%$ menghitung luas lahan

pixel_lahan $=\operatorname{sum}(\operatorname{Gambar} 2(:))$;

luas_lahan = pixel_lahan*skala_meter;

set(handles.luas_lahan,'string',luas_lahan);

handles.luaslahan = luas_lahan;

handles.pixel_lahan = pixel_lahan;

guidata(hObject, handles);

set(handles.tombol_luasserangan,'Enable','on)

Perhitungan Pixel Serangan

Perhitungan luasan serangan

penyakit tungro memakai serangkaian

algoritme sehingga antara padi yang terkena penyakit tungro dengan padi yang sehat akan bisa dibedakan.

Tahap pertama dalam perhitungan pixel serangan adalah proses thresholding otsu. Thresholding adalah tahapan untuk mengubah citra RGB menjadi citra biner. Proses perubahan citra RGB menjadi citra biner menggunakan suatu nilai ambang (T). Pada penelitian ini, nilai $\mathrm{T}$ dimodifikasi sehingga bisa mendapatkan citra biner yang sesuai program yaitu bisa membedakan padi yang terserang penyakit tungro dan yang tidak terserang. Perubahan nilai $\mathrm{T}$ ini memakai bantuan slider agar penambahan atau pengurangan nilai $\mathrm{T}$ antar citra bisa berbeda-beda dilakukan antar foto.

Setelah proses threholding otsu, dilanjutkan dengan operasi morfologi citra. Tujuan dari morfologi citra ini adalah agar hanya daerah yang terserang penyakit tungro saja yang berwana hitam, sedangkan yang tidak terserang seluruhnya berwarna putih. Setelah citra biner sudah seperti yang diharapkan, maka dilakukan proses perhitungan pixel. Perhitungan jumlah pixel dilakukan dengan menghitung berapa jumlah pixel berwarna hitam yang ada pada gambar.
Pixel yang dihitung adalah pixel yang berwarna hitam, karena merupakan pixel padi yang terserang penyakit tungro. Koding untuk perhitungan pixel serangan adalah sebagai berikut:

\section{$\%$ binerisasi}

citra $=$ handles.gambar_crop;

nilai_slider $=$ get $($ handles.slider_thresholding,

'Value');

level_graythresh = graythresh $($ citra);

citra_olah = im2bw (citra, (level_graythresh

+ nilai_slider));

$\%$ stuktur elemen yang digunakan

se $=$ strel('square',8);

se2 = strel ('square',5);

se3 = strel('square',2);

$\%$ operasi morfologi citra

closing = imclose (citra_olah, se);

dilasi = imdilate (closing, se2);

erosi $=$ imerode (dilasi, se2);

open $=$ bwareaopen $(\sim$ erosi, 700$)$;

dilasi2 $=$ imdilate $(\sim$ open, se 3$)$;

closing $2=$ imclose $($ dilasi2, $\mathrm{se})$;

open2 = bwareaopen $(\sim$ closing2, 200);

handles.sehat $=\sim$ open 2 ;

$\%$ menampilkan gambar

axes(handles.layar1)

imshow( open2);

$\%$ menampilkan informasi level

set(handles.level_thresholding,'string',level_g raythresh + nilai_slider);

guidata(hObject, handles);

sehat $=$ handles .sehat;

pixel_sehat $=\operatorname{sum}(\operatorname{seh} a t(:))$;

pixel_lahan = handles.pixel_lahan;

$\%$ menghitung luas serangan

pixel_sakit $=$ pixel_lahan - pixel_sehat;

$\%$ Presentase serangan

persen_serangan $=$

(pixel_sakit/pixel_lahan)*100;

set(handles.presentase_serangan,'string',perse

n_serangan);

handles.persensentase_serangan =

persen_serangan;

guidata(hObject, handles); 
$\%$ menghitung luas serangan dalam $\mathrm{m} 2$

skala = handles.skala;

serangan_meter $=$ pixel_sakit $*$ skala;

set(handles.m_luas_serangan,'string',serangan

_meter);

guidata(hObject, handles);

set(handles.tombol_hasil,'Enable','on')

\section{Perbandingan Persentase Serangan pada Perhitungan Program dan Manual}

Hasil uji $\mathrm{T}$ data persentase serangan tungro dari hasil program pengolahan citra dan perhitungan secara manual dapat dilihat pada Tabel 2. Berdasarkan tabel tersebut dapat diketahui bahwa hasil perhitungan program dan perhitungan manual menghasilkan data yang sama. Hal ini dapat dilihat dari besarnya $t$ critical two tail yang lebih besar dari $t$ stat.

Tabel 2. Hasil Uji T Persentase Serangan pada Perhitungan Program dan Manual

\begin{tabular}{lcc}
\hline & $\begin{array}{c}\text { Perhitungan } \\
\text { Program }\end{array}$ & $\begin{array}{c}\text { Perhitungan } \\
\text { Manual }\end{array}$ \\
\hline Mean & 19,605 & 19,180 \\
Variance & 249,230 & 257,226 \\
Observations & 12 & 12 \\
Pooled Variance & 253,228 & \\
Hypothesized & & \\
Mean & & \\
Difference & 0 & \\
Df & 22 & \\
t Stat & 0,065 & \\
P(T<=t) two-tail & 0,948 & \\
t Critical two- & & \\
tail & 2,074 & \\
\hline
\end{tabular}

\section{KESIMPULAN DAN SARAN}

\section{Kesimpulan}

Berdasarkan hasil dari penelitian yang telah dilakukan, dapat disimpulkan bahwa algoritme proram pengolahan citra yang dirancang (akuisisi citra, normalisasi warna, mosaicking citra, resize citra, perhitungan skala, perhitungan pixel serangan, perhitungan pixel lahan dan perhitungan persentase serangan) dapat menghasilkan data yang sama dengan data yang diukur menggunakan planimeter. Dari uji T didapatkan hasil bahwa kedua data relatif sama, yaitu berturut-turut sebesar $19,605 \%$ dan $19,180 \%$.

\section{Saran}

Perlu dilakukan pengembangan sehingga intensitas serangan bisa diukur. Pengukuran intensitas serangan akan berguna dalam pendugaan hasil panen karena padi yang terkena serangan dengan intensitas rendah pun akan memberikan penurunan hasil pada petani.

\section{DAFTAR REFERENSI}

Anonim. 2016. Pedoman Bantuan Premi Asuransi Usaha Tani Padi. Direktorat Jendral Prasarana dan Sarana Pertanian. http://psp.pertanian.go.id/assets/file /2016/PEDUM\%20AUTP\%2015\% 20Jan\%202016.pdf . Diakses 21 Februari 2017.

Hibino, H., Roechan, M., \& Sudarisman, S. 1978. Association of two types of virus particles with penyakit habang (tungro disease) of rice in Indonesia. Phytopathology, 68 (10), 14121416.

Menteri Pertanian. 2015. Peraturan Menteri Pertanian Republik Indonesia Nomor 40 /Permentan /SR.230/7 /2015 tentang Fasilitas Asuransi Pertanian. Jakarta. Kementerian Pertanian Republik Indonesia.

Manopo, R., Salaki, C. L., Mamahit, J. E., $\&$ Senewe, E. 2013. Padat populasi dan intensitas serangan hama walang sangit (Leptocorisa acuta thunb) pada tanaman padi sawah di Kabupaten Minahasa Tenggara. COCOS (Vol. 2, No. 3). 
Omura, T., Saito, Y., Usugi, T., \& Hibino, H. 1983. Purification and serology of rice tungro spherical and rice tungro bacilliform viruses. Japanese Journal of Phytopathology, 49(1), 73-76.

Putra, I.W.A.S., I.M.A.S. Wijaya, I.B.P Gunadnya. 2016. Kualitas Foto Udara Pada berbagai Ketinggian. Jurnal BETA (Biosistem dan Teknik Pertanian). Universitas Udayana. Jimbaran.

Siwi, S. S. dan Y. Suzuki. 1991. The green leafhopper (Nephotettix spp.): vector of rice tungro virus disease in SoutheastAsia, particularly in Indonesia and its management.
Indonesian Agricultural Research \& Development. Journal 13 (1\& 2) 815.

Sogawa, K. 1976. Rice tungro virus and its vectors in tropical Asia. Review of Plant Protection Research, 9, 21-46.

Suzuki, Y., I.G.N. Astika, I.K.R. Widrawan, I.G.N. Gede, I.N. Raga, and Soeroto. 1992. Rice tungro disease transmitted by green leafhoppers: its epidemiology and forecasting. JARQ26:98-10

Wastono, M. 2013. Foto Udara dan Citra Satelit. http://terra-image.com/fotoudara-dan-citra-satelit/. Diakses 23 Maret 2017. 